\title{
A New Species of the Genus Dactyloscirus Berlese (Prostigmata: Cunaxidae) from Egypt
}

\author{
M. M. H. Fawzy; A. M. Khalil and Hosnea A. Afifi \\ Fruit Acarology Dept., Plant Protec. Res. Inst. Agric. Res. Cent., Giza, Egypt.
}

\begin{abstract}
Dactyloscirus egyptiacus sp. nov. collected from debris under cotton cultivars at Qalyobia governorate Egypt is described and illustrated.
\end{abstract}

Key words: Dactyloscirus, Cunaxidae, Prostigmata; Egypt.

\section{INTRODUCTION}

Members of the family Cunaxidae are considered as predators suppressing some phytophagus pest's populations on plants, debris and soil. Different species were recorded all over the world, Berlese, 1888; Baker \& Hoffmann, 1948; Cooreman, 1954; Smiley, 1975 \& 1992 and Den Heyer, 1975 \& 1979). In 1981a, Den Heyer drscussed the historical background of this family and its morphological and taxonomical features. Swift, 1996 described \& illustrated the two new species Dactyloscirus hoffmann and D. smileyi from Hawaiian Islands and tritonymph of $D$. inermis.

In Egypt some studies were carried out concerning the occurrence, biology and morphology of some cunaxid species (Zaher et al., 1970; Zaher et al., 1975; Nassar, 1976; El-Bishlawy \& Rakha, 1983; Zaher, 1986; El-Khateeb, 1998 \& Khalil, 2000 and El-Naggar et al., 2007).

Berlese (1916) recorded the subgenus Dactyloscirus under the genus Scirus by the new species Scirus (Dactyloscinus) eupaloides. Thor \& Willmann (1941), elevated the subgenus to generic status, designating Scirus (Dactyloscirns) eupaloides Berlese, 1916 as its type species. Baker\&Hoffmann (1948) considered Dactyloscirus a senior synonym of Cunaxa van Heyden, 1926. Smiley (1975) revised the family Cunaxidae, retaining Dactyloscirus and redescribed D. eupaloides (Berlese,1916) and D.machairodus (Oudemans,1922).

Dactyloscirus is a valid genus in the subfamily Cunaxiinae, characterized by the presence of short and stout tarsi I-IV that terminate in large, conspicuous lateral bilobed flanges, the presence of a special sensilla on tarsus I with an elongate-base, and a distinctive reticulate ornamentation on the propodosomal plate which has subrectangular shape with $340 \mathrm{~mm}$ length and $110 \mathrm{~mm}$ width; palpus with 5 segments extending beyond the apex of hypostome, and with or without an apophysis on the palpal telofemur and palpal genu. Dactyloscirus egypticus is the first dactyloscirus species recorded in Egypt. All measurements are in micrones. Terminology follows Smiley (1992).

Holotype and paratypes are deposited at Fruit mite research Department at Plant Protection Research Institute.

\section{Dactyloscirus egypticus sp.nov. Figs 1-6}

\section{Diagnosis:}

This species looks like $D$. poppi in having lateral small shield, reticulated and transverse between $\mathrm{d}$, $\mathrm{d} 2$ with length $68 \mathrm{~mm}$ and not having a dorsal median hysterosomal shield. There is a difference in the measurements of idiosoma between $D$. poppi length and widith $986 \& 268$; while in this species being 525 $\mu$ length $437 \mu$ width.

\section{Female:}

Approximately $525 \mu$ long, and $437 \mu$ wide. Color orange. Dorsal setael designations follow those of kethley (1990). Body length measuared from posterior tip of hysterosoma to the anterior tip of propodosoma, length of leg segments from coxae to the tip of tarsal claws.

Dorsum (Fig.1): Covered with propodosoma reticulated subrectangular shield originating behind base of gnathosoma, with length 330 width $110 \mathrm{~mm}$.

Chelicerae (Fig. 3): Elongate, located dorsally over the hypostome with $240 \mathrm{~mm}$ in length, consists of three segments, the base short, the blade elongate, strong, broad posteriorly and attenuate anteriorly and the movable digit which is chela. Gnathosoma length $297 \mathrm{~mm}$ and width $175 \mathrm{~mm}$. Palpi (Fig. 6) five segments with length $343 \mathrm{~mm}$; while in $D$. poppi palpus length was $126 \mathrm{~mm}$; chaetotaxy of palpus as follows:

Hypostome (Fig. 5): Its length $297 \mathrm{~mm}$,width $175 \mathrm{~mm}$, ventral integument densely covered with reticulation around base of palp- coxal area, sub rectangular, semicone shaped distally with 2 pairs adorsal setae, and 4 pairs hypostomal setae (hg 1-4). 


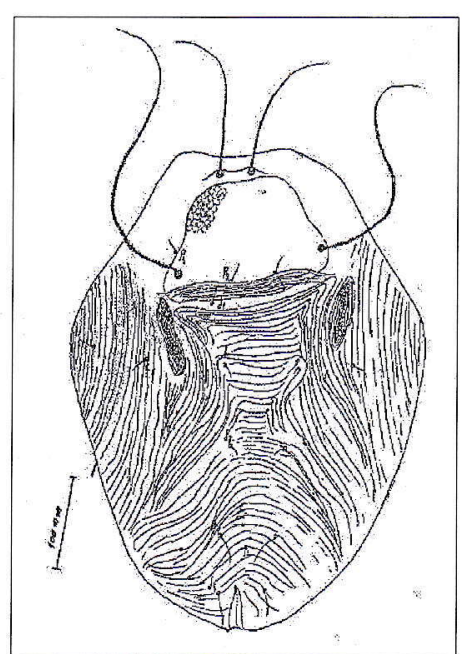

Fig. (1)

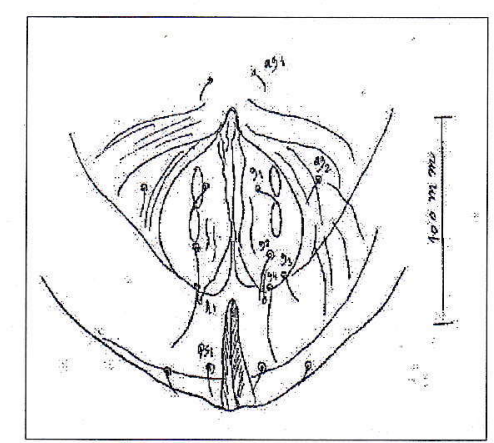

Fig. (4)

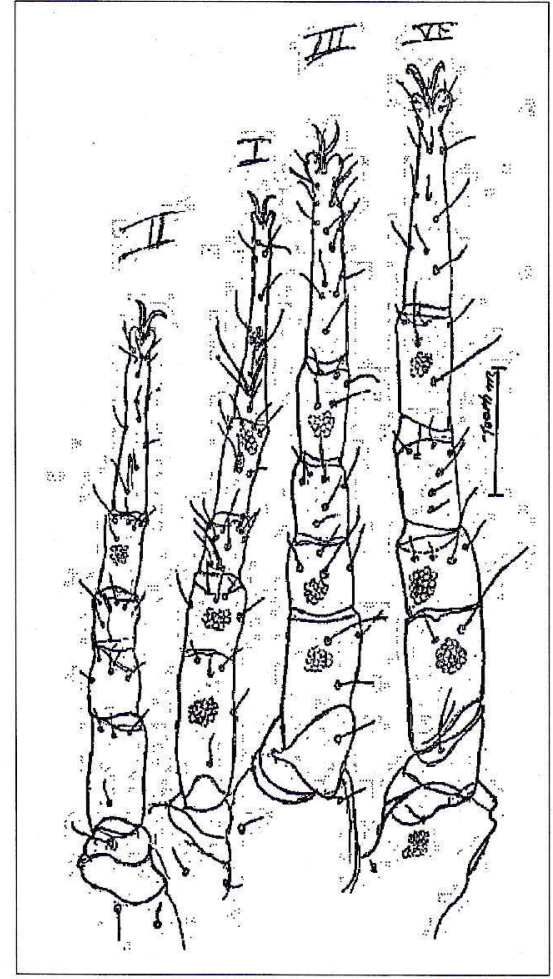

Fig. (7)

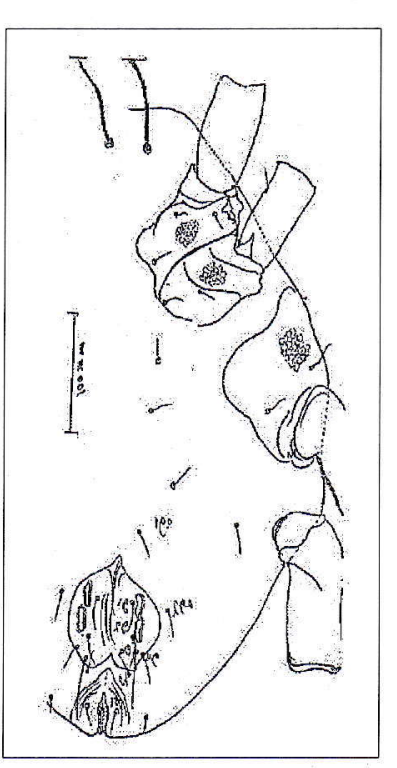

Fig. (2)

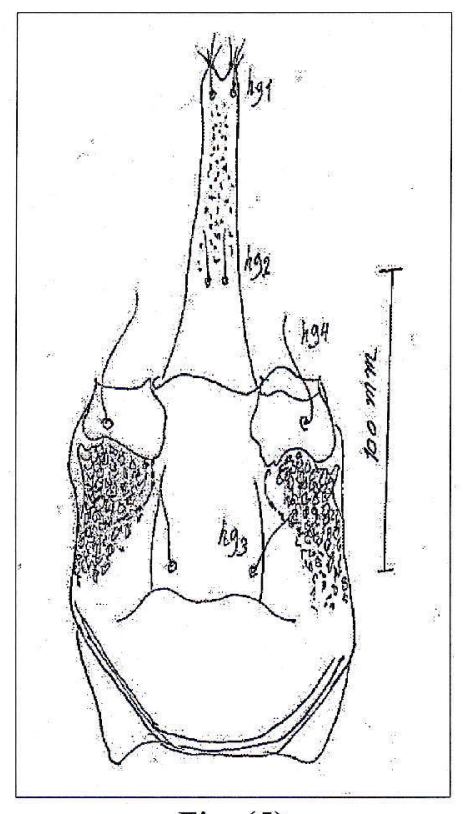

Fig. (5)

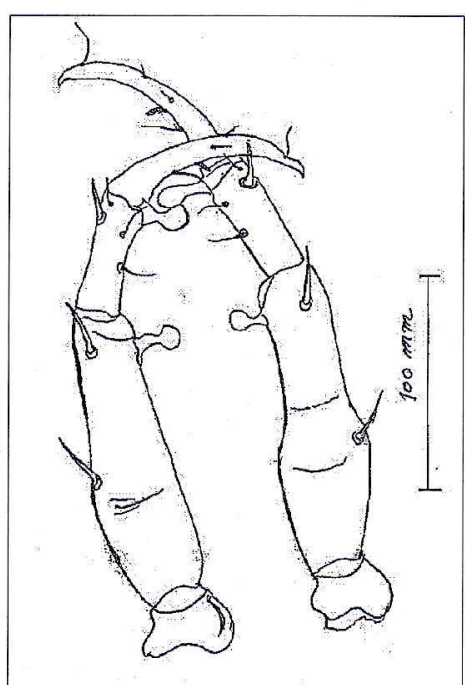

Fig. (3)

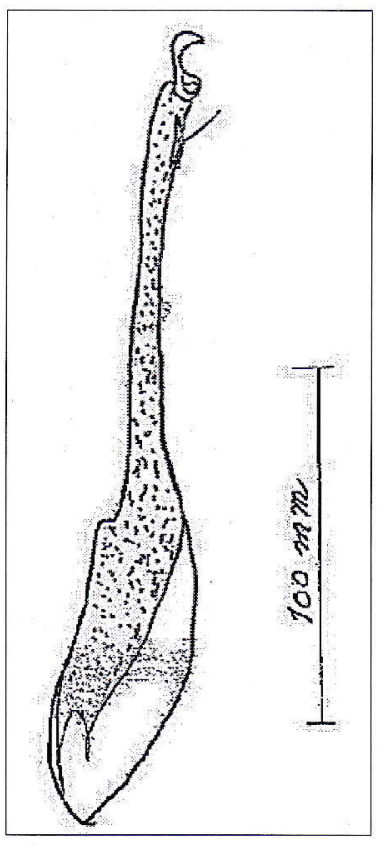

Fig. (6)

Fig. (1): Dorsum.

Fig. (2): Ventrum.

Fig. (3): Chelicerae.

Fig. (4): Genital setae.

Fig. (5): Hypostome.

Fig. (6): Palp.

Fig. (7): Legs. 
Hypostomal setal distances: (hg1-hg2) $70 \mathrm{~mm}$, (hg2-hg3) 90mm; hg4 a ciculate, long, located on hypostomal shoulder; $40 \mathrm{~mm}$ length.

Propodosomal shield with anterior and posterior sensillae 163 and $340 \mathrm{~mm}$, two pairs of propodosomal setae $\mathrm{P} 1, \mathrm{P} 2$ equal in length $8 \mathrm{~mm}$; while in $D$. poppi P1, about one-half as long as P2. Hysterosoma separated from propodosoma by small striae bearing dot-like lobes; without subrectangular reticulated mediam shield; with elongate reticulated lateral shields $68 \mathrm{~mm}$. Transverse striation between $d_{1}-d_{3}$, and a longitudinal between $P_{1}$ and the two lateral sides of idiosoma, a circle striation around lateral shields. Hysterosoma with smooth setae $\mathrm{L}_{1}, \mathrm{D}_{1}-\mathrm{D}_{5}$. Setae $L_{1}, D_{1}-D_{3}$ about equal in length $18-19 \mathrm{~mm}$ setae $D_{4}$ and $D_{5}$ about four times the length of $d_{1}$

Ventrum (fig.2): Coxae I-II contiguous, coxal shields densely covered with reticulation, connected by small lateral apodemes caxae III-IV separate, coxa III reticulate and broader than coxae I-II. Coxae I-IV setal fermula 3-2-2-2; while in D.poppi 3-2-3-2. Three pairs of simple setae located between coxae IIIV increased in length from above to bottom. Four pairs of simple genital setae (Fig. 4), g1-g3 arranged longitudinally, g4 located laterally of g3, lengths; $g 1$ 9.5, g2 19, g3 32, g4 15; while in species $D$. poppi these setae subequal. Two pairs of agenital setae (ag $1-2)$; one pair of pseudo-anal setae $\left(\mathrm{PS}_{1}\right)$ on lateral

Hypostomal setal distances: (hg1-hg2) $70 \mathrm{~mm}$, (hg2-hg3) 90mm; hg4 a ciculate, long, located on hypostomal shoulder; $40 \mathrm{~mm}$ length.

Propodosomal shield with anterior and posterior sensillae 163 and $340 \mathrm{~mm}$, two pairs of propodosomal setae $\mathrm{P} 1, \mathrm{P} 2$ equal in length $8 \mathrm{~mm}$; while in $D$. poppi $\mathrm{P} 1$, about one-half as long as P2. Hysterosoma separated from propodosoma by small striae bearing dot-like lobes; without subrectangular reticulated mediam shield; with elongate reticulated lateral shields $68 \mathrm{~mm}$. Transverse striation between $d_{1}-d_{3}$, and a longitudinal between $P_{1}$ and the two lateral sides of idiosoma, a circle striation around lateral shields. Hysterosoma with smooth setae $L_{1}, D_{1}-D_{5}$. Setae $L_{1}, D_{1}-D_{3}$ about equal in length $18-19 \mathrm{~mm}$ setae $\mathrm{D}_{4}$ and $\mathrm{D}_{5}$ about four times the length of $\mathrm{d}_{1}$

Coxae I-II Fig. (7) contiguous, coxal shields densely covered with reticulation, connected by small lateral apodemes caxae III-IV separate, coxa III reticulate and broader than coxae I-II. Coxae I-IV setal fermula 3-2-2-2; while in D.poppi 3-2-3-2. Three pairs of simple setae located between coxae IIIV increased in length from above to bottom. Four pairs of simple genital setae (Fig. 4), g1-g3 arranged longitudinally, g4 located laterally of g3, lengths; g1 9.5, g2 19, g3 32, g4 15; while in species $D$. poppi edge of anal shields, setae $h_{2}$ located ventrally, adjacent to anal shield cupule in aligned posteriorly nearby.

Legs (Fig. 7): Trochanter none; basifemur with one dorsal spinelike seta, telofemur with dorsomedial spine-like setae and inner lateral apophysis like mushroom; while in D. Poppi not as in D. egyptiacus; genu inner surface with one medially long simple seta; and a spine seta at its lateral tip; Tibiotarsus inner surface basally with mushroom apophysis, medially with long simple setae; above this setae a short rod-like apophysis; adjacently with ventral simple setae; outer surface with dorsolateral simple setae, terminal with simple setae and small claw.

Length of I-IV: 487, 450, 550 and $575 \mathrm{~mm}$ leg IV the longest tarsi I-IV not tapering. Number of setae on leg segments I-IV (setae on lateral lobed flanges of tarsus not included) coxae I-IV: 2,2,3,2, trochanters, 1,1,1,1; basifemora: 5,4,3,2; telofemora; $5,5,4,4$ gena $1-4 ; 1$ solenidia blus 8 setae; 1 solenidia blus 6 setae; 6 setae and 7 setae; tibiae I-IV: 7,5,5,5; tarsus I\&II attenuate, 1 tapring solenidia in the base + 13 setae; while tarsus III and IV with: 13 and 10 setae.

\section{Types:}

Holotype female from debris under cotton cultivars in Qalyobia governorate, Egypt +2 paratypes kept in the collection of Fruit Mite Research Department, Plant Protection

these setae subequal. Two pairs of agenital setae (ag 1-2); one pair of pseudo-anal setae $\left(\mathrm{PS}_{1}\right)$ on lateral edge of anal shields, setae $h_{2}$ located ventrally, adjacent to anal shield cupule in aligned posteriorly nearby.

Legs (Fig. 7): Trochanter none; basifemur with one dorsal spinelike seta, telofemur with dorsomedial spine-like setae and inner lateral apophysis like mushroom; while in D. Poppi not as in D. egyptiacus; genu inner surface with one medially long simple seta; and a spine seta at its lateral tip; Tibiotarsus inner surface basally with mushroom apophysis, medially with long simple setae; above this setae a short rod-like apophysis; adjacently with ventral simple setae; outer surface with dorsolateral simple setae, terminal with simple setae and small claw.

Length of I-IV: 487, 450, 550 and $575 \mathrm{~mm}$ leg IV the longest tarsi I-IV not tapering. Number of setae on leg segments I-IV (setae on lateral lobed flanges of tarsus not included) coxae I-IV: 2,2,3,2, trochanters, 1,1,1,1; basifemora: 5,4,3,2; telofemora; $5,5,4,4$ gena $1-4 ; 1$ solenidia blus 8 setae; 1 solenidia blus 6 setae; 6 setae and 7 setae; tibiae I-IV: 7,5,5,5; tarsus I\&II attenuate, 1 tapring solenidia in the base + 13 setae; while tarsus III and IV with: 13 and 10 setae. 


\section{Types:}

Holotype female from debris under cotton cultivars in Qalyobia governorate, Egypt +2 paratypes kept in the collection of Fruit Mite Research Department, Plant Protection Research Institute, Dokki Giza, Egypt.

\section{ACKNOWLEDGMENTS}

The authors gratefully acknowledge Dr. Rakha, M. A. and Halawa, A. M. Professors of Acarology, Plant Protection Research Institute, for reviewing the manuscript, critical comments and valuable advices.

\section{REFERENCES}

Baker, E. W. and Hoffmann, A.1948. Acaros de la familia Cunaxidae. An. Esc. Nac. Cicnc. Biol. Mex., 5(3-4): 229- 273.

Berlese, A.1888. Acari Austro Americani Buos Collegit Alosyius. Balzan.Soc. Entomol. Ital., 20: 188, pl. 7.

Berlese, A.1916. Centuria Terza di Acari. Redia, 12: 289-338.

Cooreman, J. 1954. Notes sur quelques Acariens de la faune Cavernicole. Inst. Roy. De Sci. nal. De Belg., 30(34): 1-18.

Den Heyer, J. 1975. A new genus Cunabdella (Prostigmata: Acari) with a description of a new species from the Ethiopian region. Acarologia, 16(4): 664- 670.

Den Heyer, J.1979. Coleoscerinae, a new cunaxid subfamily and two new South African species of Coleascirus Berlese 1916(Acari: Prostigmata) Acarologia, 20(4):522 -554.

Den Heyer, J. 1980. Pulaeus, a new cunaxid genus (Acari: Prostigmata) Acarologia, 21(1):18-33.

Den Heyer, J. 1981a. Systematic of the family Cunaxidae Thor, 1902. Publ. Univ. of the North Ser. A., 24: 1-19.

Den Heyer, J.1981b. Three new Afro-tropical species of the genus Pulaeus (Acarida: Actinedida). Phytophylactica, 13: 87- 99.

El-Bishlawy, S.M. and Rakha, M. A.1983. A new species mite Pulaeus zaherii sp.n. from Rat Burrows in Egypt (Actinedida) Cunaxidae. Acarologia, 24(4): 373-375.

El-Khateeb, H. M. 1998. Life tables of some predaceous mites and their importance in biological control. Ph. D. Thesis, Fac., Agric.
Cairo Univ.119 pp.

El-Naggar, M. E.; Magda Kh-Megalli; Aziza H. Omar; M. M. El shazly and Mona M. Ghallab. 2007. First recored of Pulaeus subterraneus Berlese, Male, with comparison between the tritonymphal stage of two sexes (Acari: Cunaxidae). Acarines, 1:39-43.

Ghallab M. M. 2002. Ecological, biological and morphological studies on some predaceous mites (Suborder: Actinedida) Ph.D. Thesis, Fac. Sc. Cairo Univ. 244 pp.

Khalil, A. M. 2000. Ecological and biological studies on some mites (Suborder Actinedida). M. Sc. Thesis, Fac. Agric. Al-Azhar Univ., 119 pp.

Nassar, O. A. 1976. Incidence of predaceous mites on fruit trees in North East of Delta with emphasis on Cunaxa setirostris (Hermann). M Sc. Thesis, Fac. Agric. Cairo Univ., 91 pp.

Sepasgosarian, H.1984. The world genera and species of the family Cunaxidae (Acarida: Actinedida) Zeit. Ang. Zool., 71: 135 -150.

Smiley, R. L. 1975. A generic revision of the mites of the family Cunaxidae (Acarina). Ann. Entomol. Soc. Am., 68(2): 227 -244.

Smiley, R. L. 1992. The predatory mite, family Cunaxidae (Acari) of the world with a new classification. Indira Publishing House, West Bloom Field Michigan USA, 355 pp.

Swift, S.F. 1996. Two new species of Dactyscirus (Acari: Prostigmata: Cunaxidae) in Hawaiiam islands. Anal. Inst. Biol. Univ. Nac. Autom. Mexico, Ser.2001, 67(2):225-237.

Thor, S. and Willmann, C. 1941. Acarina Prostigmata (Eupodidae, Penthalodidae, Penthaleidae, Pachignathidae, Cunaxidae) Das. Tierreich, 71a: $1-186$.

Zaher, M. A. 1986. Survey and ecological studies on phytophagous, predaceous, and soil mites in Egypt. II- A Predaceous and non- predaceous mites (Nile Valley and Delta). PL 480 Program USA Project No. EG-ARS-30. Grant No. FG-139.

Zaher, M. A.; Soliman, Z. R. and El-Bishlawy, S. M. 1975. Feeding habits of the predaceous mite Cunaxa capreolus Berlese (Acari-Cunaxidae). Entomophaga, 25(2): 209-212.

Zaher, M. A.; Wafa, A. K.; Maher, A. M. and Rasmy, A. H. 1970. General survey of mites associated with citrus trees in Egypt and Gazza Strip. Bull. Soc. Entomol. Egypt, 54: 73 -79. 